\title{
Marriage Function as Protection Rights Against Wife and Children Right in Polygamous Marriage
}

\author{
Muhammad Madih¹, I Dewa Putu Gede Anom Danujaya² and Munsyarif \\ Abdul Chalim ${ }^{3}$
}

Abstract. Marriage is a bond between man and woman which is also the religion of Islam is a way of worship, that in the community there is monogamy: one husband and one wife, but there are also polygamous marriage is one man with more than one wife with their applicable laws and regulations for implementation. The purpose of this study was to: 1 ) To determine the function of the marriage covenant can provide legal protection of the rights wife and children in polygamous marriages. 2) To determine the right of wife and children in polygamous marriages. 3) To know the legal remedies can be done to determine the rights of wives and children in polygamous marriages. Based on the results of data analysis concluded that: 1) The function of the marriage contract may provide legal protection of the rights of the wife and children in polygamous marriages as a certainty or limitation of rights received by his wife and children during the marriage took place and as a measure for husbands to act fairly in polygamous marriages , 2) The position of the right wife and children in polygamous marriages, namely the right wife by the husband proportionate balanced well after their second marriage and so are the rights of children still get their right in accordance with the provisions of the Act. 3) Remedies that can be done to determine the right istir and children in polygamous marriages with authentic mating agreements made governing the boundary between the rights and obligations of husband and wife in a polygamous marriage.

Keywords: Marriage; Polygamy; Marriages Agreement; Wife and Children's Rights.

\section{Introduction}

As individual human beings need other people to sustain life. There is no man who can hold his life by relying on its own merits. To establish offspring for generations later, people have to do weddings. ${ }^{4}$

Constitution of the Republic of Indonesia in 1945 of Article 28 B, paragraph 1 states that "everyone has the right to form a family and continue the descent through legal marriage. In essence, marriage is inner and outer bond between men with the women to form a happy family and eternal.

In Act No. 1 of 1974 About Marriage states that "marriage is inner and outer bond between a man and a woman as husband and wife in order to establish a happy and lasting families based on God". 5

In Article 1 of Act No. 1 of 1974 On Marriage aimed at arranging the perfect social life, happiness, and everlasting in a household in order to create a sense of compassion

\footnotetext{
1 Students Master of Notary Faculty of Law UNISSULA, Semarang E-mail: madihmuhammad141095@gmail.com

2 Students of Master of Law, Faculty Of Law, Universitas Islam Sultan Agung email dewa.anom85@gmail.com

${ }^{3}$ Lecturer of Faculty of Law UNISSULLA.

${ }^{4}$ Beni Ahmad Saebani, Perkawinan Dalam hukum Islam dan Undang-Undang,(prespektif Fiqih Munakahat Dan UU No. 1/1974 Tentang Poligami dan Problematikanya), Bandung, CV Pustaka Setia, 2008, p. 16

${ }^{5}$ Act No. 1 of 1974 About marriage
} 
and love. Forming an eternal family and happy. The desire to establish an eternal family represents the ideals of every family. But in fact that the question of marriage in Indonesia in general, not just the problem of husband and wife, but also the problem of the relatives, who participated feel good marriage continues. ${ }^{6}$

Act No. 1 Of 1974 about Marriage really cling to the rules that exist in Islamic law. Although not explicitly regulate the harmonious marriage. But the Act passed me the validity of a marriage entirely to the regulations stipulated by religious people who will hold the marriage. However, the Act regulates the terms of marriage.

Marriages under Islamic law, called the marriage, that is one of the principles key life in society civilized and perfect, because according to Islam that the wedding is not only one way that is very precious to organize domestic life and heredity, but also as a way to introduction between the door with the other one. ${ }^{7}$

In law Isalam, marriage is a contract is a contract that justifies the association (sexual intercourse) and restrict the rights and obligations and mutual help between men and women are not mahram woman, if a man and a woman have agreed between them to form a household, the husband and wife should both candidates should first perform the marriage ceremony. ${ }^{8}$

In Islam marriage means marriage or contract very strong in executing or obey God's instructions and execute a marriage of worship and aims to realize the domestic life sakinah, mawaadah, warrahmah (peace, peace, love and affection). ${ }^{9}$ Marriage is also a sacred bond in which two people of the opposite sex to live together with religious guidelines and sanctioned by their families, and communities. ${ }^{10}$

The occurrence of a bond of marriage is not solely carry due to the relations of civil as rights and obligations of husband and wife, joint property position of the child, the rights and obligations of parents also about relationships customs of inheritance, kinship, kinship and neighborhoods as well as concerning the ceremonies traditional and religious. ${ }^{11}$

Everyone wants the creation of a happy family in marriage with the love and affection that make up a marriage, but in every marriage there are issues that arise that can lead to fights that led to the desire for a husband to practice polygamy.

There are several kinds of marriage in society, but that is widely used is monogamous and polygamous marriages. From the shape of this marriage, monogamy is considered a type of marriage that is the most ideal and appropriate thing to do, monogamy is a marriage between a male with a female which, in principle, that the husband has one wife and vice versa (Article 27 of the Civil Code and Article 3 paragraph 1 of the Marriage Act) adheres to the principle of absolute monogamy. Although monogamy is a marriage that is considered most appropriate, but in many communities is also conducting polygamous marriage.

\footnotetext{
${ }^{6}$ Martiman Prodjohamidjojo, 2011, Hukum Perkawinan Indonesia, Jakarta: Indonesia Legal Center Publishing.

${ }^{7}$ Sayuti Thalib, 1974, Hukum Keluarga Indonesia, Jakarta, UI Presp. 47

8 Bakri A Rahman dan Akhmad Sukardja, 1981, Hukum perkawinan Menurut Hukum Islam Undang-Undang Perkawinan dan Hukum Perdata/BW, Jakarta, Hidakarya Agung, p 11

${ }^{9}$ Ahmad Rofiq, 1995, Hukum Islam di Indonesia, Jakarta, Raja Grafindo Persada, p 60

10 Tinarbuka.aw.studen-blog.undip.ac.id/2012/05/hukum-pernikahan-perkawinan-dalam-islam, accessed on March 2, 2019

${ }^{11}$ H. Hilman \& Hadikusuma, 2007, Hukum Perkawinan Indonesia Menurut Perundangan Hukum Adat dan Hukum Agama, Bandung, Mandar Maju, p 8
} 
In Article 3, paragraph 2, Article 4 and Article 5 of the Marriage Act regulates polygamous marriages, despite the lack of legislation governing polygamous marriages.

Polygamy is a form of marriage in society that raises the pros and cons, which in polygamous marriages are allowed a man has a wife of one man. ${ }^{12}$ In Marriage Act 1 of 1974 Article 3, paragraph 1 that marriage in principle, a man can only have a wife and a woman may only have a husband, but the principle is not absolute monogamy only to complicate the occurrence of polygamous marriages, not to abolish polygamy.

In polygamous marriages each wife has the same rights, whether the first wife or the second wife both physically and spiritually, the same lifetime guarantee to all wives and children. All the wives have the same rights or property that have occurred since their marriage had been performed. ${ }^{13}$ But in prosenya could happen any dispute between the first and second wives isti.

In the implementation of their treaty-making mating desired by the first wife to protect its rights with her children in the future if decided in a marriage that can be caused divorce or the husband dies so that no problems have arisen.

Based on the description of the background mentioned above, while the issues raised were "Marriage Function As Protection Rights Against Wife And Children Right In Polygamous Marriage".

\section{Research methods}

The method used in this research is the socio-juridical. Namely juridical sociological study of the real state of society or community environment with the intent and purpose of finding facts with observations in accordance with the formulation of the problem, juridical research conducted by examining the legal materials that are secondary data, and also referred to research that studied the books law books and other documents related to the study of the sociological research conducted in the field researching dengancara which is the primary data.

\section{Results and Discussion}

\subsection{Marital Agreements Function Can Provide Legal Protection of the Rights of Wife and Children In Polygamous Marriages}

The marriage contract is defined as one of the laws regarding the transportation of property wealth between two parties, where one party promises or considered to promise to do something, whereas other parties entitled to demand the implementation of this promise. ${ }^{14}$

Agreements are generally made for the benefit of legal protection against default property of each husband or wife. Although the Act does not regulate the purpose of mating and what agreements can be agreed, everything handed on both sides.

Mating agreement can be made by the parties before or during the marriage took place and also DAPT changed according to the will by the parties concerned and not

12 Supardi Mursalin, 2007, Menolak Poligami Studi Tentang Undang-Undang Perkawinan dan Hukum Islam, Yogyakarta, Pustaka Pelajar, p 15

${ }^{13}$ Cik Hasan Bisri, 1999, Kompilasi Hukum Islam, Jakarta, Logos Wacana Ilmu, p 145

${ }^{14}$ H.A. Damanhuri, 2012, segi-segi Hukum Perjanjian Perkawinan Harta Bersama, Bandung, Mandar Maju, p 14 
merugigan for the parties or third parties contained in Article 29 of the Marriage Act jo. Constitutional Court Decision No. 692015

The prospective husband and wife prior to marriage or the marriage took place can make the marriage contract that deviate from the rules of common property as long as it is not contrary to good morals or general rules.

Agreement Marriages are made to respect the dignity of each party and to ensure the limitation of rights and obligations to be performed by Siami and wife, but the marriage pologami marriage contract is essentially a great deal about the certainty of the rights and obligations of the parties shall be done include the agreement of the wife, the certainty that the husband is able to guarantee the necessities of life wives and their children, as well as the assurance that the husband would be fair to their wives and their children.

Marital agreement can ensure separation of inheritance to a wife, good for any marriage that exists is the first marriage, second, third and fourth in the presence Jamina of restrictions such property for the creation of mid life without dissension and disputes among heirs.

\subsection{Position Wife's Rights and Children In Polygamous Marriages}

Each wife has the same rights, whether it's first wife, second, third and fourth both physically and mentally, the guarantee of life similar to all wives and children, all the wives have the same rights on property that occurred since the marriage each have been done. ${ }^{15}$ In polygamous marriages in which the wife and children vulnerable lack rights should they get so that their marriage contract that guarantees the rights that should be accepted by the wives and children can be met.

In this case the rights that should be received by his wife and children in the form of protection in a broad scope, provides every necessity of home life according to his ability, giving the cost of treatment, providing maintenance costs, provide biyaya education and learning opportunities, providing a living mental and spiritual, giving the residence as shelter and protection.

\subsection{Remedies Can Be Done To Determine Rights of Wife and Children In Polygamous Marriages.}

Remedies can be done in this case that with the holding of the Marriage Treaty compatible with the will of the parties of the parties so as to ensure that his wife and children can receive the rights they are supposed to get.

But the Act has not set any sanctions in case of negligence of the husband of the liability. So in case of a husband negligence in fulfilling their obligations firm not subject to sanctions. Due to the application for polygamy in the Religious their statement of readiness husband untu fulfill its obligations is a requirement and not a decision that is permanent or approval above unilaterally where the husband said he would be fair and to meet its obligations as a husband, so that in case kelalainan husband to perform its obligations husband and wife can only sue in court for the husband to perform his duty without their execution.

By contrast, if a Marital Agreement legalized by Notary can do execution based on the contents of Marriage Agreement which have been agreed by both parties because the agreement is valid as the Law for the parties.

\footnotetext{
${ }^{15}$ Cik Hasan Bisri, op.cit, p.145
} 
Thus, if one party does not implement the agreement and harm others, then to the injured party can demand their rights to justice both demand the implementation of the agreement as well as demands for compensation. In Article 51 Compilation of Islamic Law marital agreement entitles the wife to ask for the cancellation of marriage or divorce to file a lawsuit alsan Religious Courts. As for the claims for compensation, if viewed any breach of a treaty can be submitted to the court to claim damages against the agreement is not implemented or not met.

\section{Closing}

\subsection{Conclusion}

Based on the research results can be concluded as follows

- Marriage agreements can be made before or when the marriage took place. The marriage agreement was held to protect the dignity of each party and also to protect the rights and obligations that must be made or received by the parties. Marital Agreements in polygamous marriages where the husband stated include the ability to do justice to the wives and children should, in this case the existing joint property during the marriage took place.

- Position in the possession of each of the wives and children in polygamous marriages have the same rights both spiritually and physically is where every wife and children get every necessity of home life according to his ability, giving the cost of treatment, giving out the maintenance costs, provide biyaya education and learning opportunities, providing a living, provide residence.

- Remedies can be done in determining the rights of his wife and children by performing the Agreement marriages performed before a Notary which contains the provision of rights that must be accepted wife and son are in accordance with the needs and if the husband ingkat may be filed with the Court and can be executed in accordance with content in a Marital Agreement. As not made an agreement made before a Notary marriage can still be applied to court for husbands to fulfill its obligation to meet his wife and child need.

\subsection{Suggestion}

- Marital agreements must be made carefully in accordance with the needs of the parties in order to avoid future disputes with the provisions of the rights and obligations which must be accepted and must be implemented by the parties

- In accepting the right of each of the wives and children should be equally without exception in order to create a good atmosphere and quiet in household life

- Ensure that the parties are either wives or husbands understand that pentinggnya a marriage for melingdungi Treaty obligations and rights they have to enforce and should they receive so that the absence of negligence that resulted in harm either party in a polygamous marriage.

\section{Bibliography}

[1] Ahmad Rofiq, Hukum Islam di Indonesia, 1995, Raja Grafindo Persada, Jakarta 
[2] BeniAhmad Saebani, Perkawinan Dalam hukum Islam dan UndangUndang,(prespektif Fiqih Munakahat Dan UU No. 1/1974 Tentang Poligami dan Problematikanya), 2008, CV Pustaka Setia, Bandung

[3] Bakri A Rahman dan Akhmad Sukardja, Hukum perkawinan Menurut Hukum Islam Undang-Undang Perkawinan dan Hukum Perdata/BW, 1981, Hidakarya Agung, Jakarta

[4] Cik Hasan Bisri, Kompilasi Hukum Islam, 1999, Logos Wacana Ilmu, Jakarta

[5] H. Hilman \& Hadikusuma, Hukum Perkawinan Indonesia Menurut Perundangan Hukum Adat dan Hukum Agama, 2007, Mandar Maju, Bandung

[6] Martiman Prodjohamidjojo, Hukum Perkawinan Indonesia, 2011, Indonesia Legal Center Publishing, Jakarta.

[7] Sayuti Thalib, Hukum Keluarga Indonesia, 1974, UI Pres, Jakarta

[8] Supardi Mursalin, Menolak Poligami Studi Tentang Undang-Undang Perkawinan dan Hukum Islam, 2007, Pustaka Pelajar, Yogyakarta

[9] Act No. 1 of 1974 About marriage

[10] Blog: Tinarbuka.aw.studen-blog.undip.ac.id/2012/05/hukum-pernikahanmarriage-in-Islam, accessed on March 2, 2019 